\title{
COMPETITION ASPECTS OF PUBLIC LICENSES
}

\author{
by \\ TOMÁŠ KUBEŠA*
}

Public licenses have earned a strong position in both protection and transfer of Intellectual Property Rights. Public licenses are an essential part of activities of many companies, projects and even research grants and their use is increasing. This development means that IPRs and related products protected by public licenses engage in competition with products, protected by more traditional licensing schemes. Thus, even public licenses must be assessed through competition law scrutiny. Recent case law and scientific work ${ }^{1}$ clearly show that viewing public licenses through competition law perspective is a difficult task and requires a deep legal assessment and debate. Many known competition concepts, such as price fixing $^{2}, R P M^{3}$ or abuse of dominance $e^{4}$ do not seem to cope well with many common provisions of public licenses. This article will summarise existing state of such debates, introduce competition law concepts into the context of public licenses and offer a solid competition viewpoint of public licenses. The outcome of this article will answer the question whether and when can public licenses breach competition law rules.

\section{KEY WORDS}

Competition, Public Licenses, Market Definition, Enforcement, Cartel

\section{PUBLIC LICENSES, COMMON PROVISIONS}

Public licenses can be viewed as a means of providing the author the freedom to dispose with his works freely and offer more possible

\footnotetext{
tomas.kubesa@mail.muni.cz, Ph.D. candidate at Faculty of Law, Masaryk University.

Välimäki, M. 2005, Rise of Open Source Licensing, Turre Pulishing, Helsinki, p. 78.

Art. 101, par. 1 let. a) Treaty on the Functionuing of the European Union.

Ibid.

4 Art. 102 TFEU.
} 
choices than traditional copyright ${ }^{5}$. They also provide legal certainty to users of works created by authors, who have decided not to enforce some of the rights granted by copyright protection.

Public licences also show a specific contractual process. In this process, the author offers his work publicly to an undefined number of recipients (for example online) with a reference to the license and its terms ${ }^{6}$. The license and its terms is to be provided by a third party for use by other licensors. The other contractual party, the licensee, accepts the license and its terms by specific performance, usually by simply using the work in question. The third party that provides the license and its terms can guarantee the quality of the license. It also plays an important role in preventing conflicts between different public licenses in derivative works.

The contractual process can be altered in many ways, such as by using a license drafted specifically for a transaction, by offering the work in question to a selected audience only or by using a different form of accepting the license. These changes, however, do not alter the substantive nature of the public license. It is important to notice, that any alterations to the contractual process can lead to unnecessary difficulties in using the licensed works later.

At this point, we can identify many different public licenses. Some can be used generally for a wide range of work while others are more suitable for more specific types of works, such as databases ${ }^{7}$, public sector information ${ }^{8}$ or software ${ }^{9}$. As mentioned above, anyone can create their own public license therefore a definitive, exhaustive list cannot be established. Some of the most influential licenses discussed in this article include the Creative Commons, GNU GPL, EUPL ${ }^{10}$ and others.

Most of the public licenses contain a few significant common provisions. Although their exact wording can differ, the underlying concept remains

\footnotetext{
About Creative Commons, available at http://creativecommons.org/about.

About the Licenses, available at http://creativecommons.org/licenses/.

For example the Open Database License, available at:

http://opendatacommons.org/licenses/odbl/1.0/.

8 For example the License to Re-Use Public Sector Information under European Communities, available at http://psi.gov.ie/files/2010/03/PSI-Licence.pdf.

9 For example the GNU GPL, available at http://www.gnu.org/copyleft/gpl.html.

10 European Union Public License, available at: http://ec.europa.eu/idabc/servlets/Docbb6d.pdf?id=31979.
} 
similar. Such provisions concern the attribution requirements ${ }^{11}$, distribution requirements ${ }^{12}$, (lack of) remuneration, the possibility of use in derivative works $^{13}$ and alterations of the work $^{14}$, possibility of commercial use ${ }^{15}$, liability clauses ${ }^{16}$ and licensing requirements ${ }^{17}$. These provisions form the core of the public license and are of most significance also for the antitrust scrutiny. They form a closely connected bond; however can also be assessed separately.

The attribution provisions ${ }^{18}$ set the obligation to indicate the author of the work, the title of the work and the original source. Depending on a license, the exact form of the attribution clause can differ as well as the amount of information provided according to it.

The distribution provisions ${ }^{19}$ indicate whether it is possible to distribute the work further and what criteria must be met for such distribution.

The remuneration provisions set the price of the work. In public licenses, this price is set as zero - that is the works are provided for free. This provision has significant impact to many aspects of the work and its use, such as taxation or accounting.

The derivative provisions ${ }^{20}$ state whether it is possible to use the work in other, derivative works and the conditions that must be met for such use.

The alteration provisions ${ }^{21}$ set the conditions that are to be met when the work is being altered and whether such alterations are possible.

The commercial use provisions ${ }^{22}$ set, whether it is possible to use the work in a commercial manner. They might also set ways, that are considered commercial and those that are not.

11 For example the wording in Creative Commons v. 4.0 available at: http://creativecommons.org/licenses/by/4.0/legalcode.

12 For example the wording in Creative Commons v. 4.0 available at: http://creativecommons.org/licenses/by-sa/4.0/legalcode.

13 For example the wording in Creative Commons v. 4.0 available at: http://creativecommons.org/licenses/by-nd/4.0/legalcode.

14 Ibid.

15 For example the wording in Creative Commons v. 4.0 available at: http://creativecommons.org/licenses/by-nd/4.0/legalcode.

16 Ibid.

17 Ibid.

18 See footnote 11 above.

19 See footnote 12 above.

20 See footnote 13 above.

21 Ibid.

22 See footnote 15 above. 
The liability clauses limit the extent of the liability of the author or license provider. Commonly, they limit the liability to the least possible extent $^{23}$.

The licensing clauses set potential limitations to the type and content of a license to be used for distributing the works and its derivative works or alterations ${ }^{24}$.

It is possible to conclude, that most public licenses contain similar provisions. Therefore, it is possible to use this list for further assessment of public licenses in competition law in general, without the need to limit the argument to a specific public license. Some public licenses may contain provisions that alter the general meaning of the provisions as described above $^{25}$, however they will be omitted in this article.

\section{COMPETITION AND ITS ABUSES}

Competition regulation follows a general goal of consumer welfare that is provided by competition among undertakings that engage in an economic activity. These undertakings generate pressure on each other to raise quality, lower prices and innovate in order to keep the pace or overcome their competitors ${ }^{26}$. Under competition law, collusion among such undertakings can be harmful as it restricts the competition and does not lead to the desired outcome. Instead, uncertainty for all market players is believed to be beneficial as it keeps the pressure on the competitors. Those competitors that cannot keep the pace are eventually driven out of the market. It is possible to conclude, that competition law provides a negative motivation for competition.

Copyright and IP rights in general follow a different path. They provide a well-defined protection to an author or originator of a work or invention. Under such protection, the authors or originators can exploit their work or invention in an economical way, without disruptions from other market players. The consumer welfare is achieved by motivating market players to gain such protection, innovation and growth spurs on the way to this

${ }^{23}$ For example the wording in Section 5, Creative Commons v. 4.0 available at: http://creativecommons.org/licenses/by-nc/4.0/legalcode.

${ }^{24}$ For example the wording in Section 2, Art. 5 Creative Commons v. 4.0 available at: http://creativecommons.org/licenses/by-nc/4.0/legalcode.

${ }^{25}$ For example some copyleft licenses do not require the licensor to use the attribution provisions.

26 Antitrust Overview, European Commission. Available at: http://ec.europa.eu/competition/antitrust/overview_en.html. 
goal $^{27}$. We can conclude that IP law provides a positive motivation for competition.

As stated above, competition law and IP law, including copyright, follow similar goals. However, we can still detect signs of conflict between these two fields of law that cannot be resolved in a way introduced above. One of such conflicts is the competition assessment of public licenses.

Competition regulation recognises a wide range of abuses of competition. Many of them seem relevant to public licensing, at least at first glance.

We can sort the abuses into two main groups, horizontal and vertical practises. The horizontal practises involve undertakings on the same level of the market chain. These undertakings are to engage in competition ${ }^{28}$. The vertical practises involve undertakings on different levels of the market chain, usually a supplier and a purchaser or customer (not necessarily a consumer on this stage). These undertakings do not engage in competition among each other; however their actions might have effect on consumers or other market players ${ }^{29}$.

The most dangerous among the horizontal practises are the cartels ${ }^{30}$. In a cartel, the undertakings set price levels or business conditions, agree to exclude others from their business activities or refuse access to essential facilities they hold $^{31}$. The cartel activities include also other subjects not necessarily active on the given relevant market. These are the cartel facilitator, who is a third party enabling the cartelists collusion or the association of undertakings, where the competitors meet with a legitimate aim that develops into a collusive practise.

Among the vertical practises, the most important practises recognised are the abuse of dominance ${ }^{32}$ and a vertical agreement ${ }^{33}$.

27 Art. 7 TRIPS Agreement, available at:

http://www.wto.org/english/tratop_e/trips_e/t_agm2_e.htm.

28 Cartels Overview, European Commission. Available at:

http://ec.europa.eu/competition/cartels/overview/index_en.html.

29 The Competition Rules for Supply and Distribution Agreements, 2012, European Commission, available for download at http://bookshop.europa.eu/en/the-competitionrules-for-supply-and-distribution-agreements-pbKD3211986/.

${ }^{30}$ See footnote 28 above.

31 Rose, V., Bailey, D. 2013, European Union Law of Competition, Oxford University Press, Oxford, p. 282.

${ }^{32}$ Art. 102 TFEU.

33 Art. 101 TFEU. 
Under the abuse of dominance ${ }^{34}$, a dominant undertaking uses its market power to harm its remaining competitors. The core requirement to be met to declare an abuse is market dominance or a dominant position. An undertaking is dominant when it is able to act independently on its suppliers, customers and competitors in the terms of prices and business conditions it offers ${ }^{35}$. Dominance is usually considered with undertakings that exceed a certain size of a market share, however this presumption can be rebutted ${ }^{36}$. A dominant undertaking is restricted from certain market activities, such as dumping or margin squeeze ${ }^{37}$.

A vertical agreement is recognised among suppliers and customers in the supply chain. The parties to such agreement fix their prices or agree on business conditions offered further down the supply chain ${ }^{38}$.

The common element of the abovementioned abuses is an agreement between market players on prices or business conditions to be offered to their customers, limits on production or similar restrictions. It is well documented, that such conduct limits the effectivity, creates inefficiencies, increases prices and reduces consumer welfare ${ }^{39}$.

\section{RELEVANT MARKET IN PUBLIC LICENSING}

An important concept in competition law and in the assessment of any possible infringement is the relevant market ${ }^{40}$. A relevant product market is defined as comprising of all those products and/or services which are regarded as interchangeable or substitutable by the consumer, by reason of the products' characteristics, their prices and their intended use ${ }^{41}$. The relevant geographic market comprises the area in which the undertakings concerned are involved in the supply and demand of products or services, in which the conditions of competition are sufficiently homogeneous

\footnotetext{
34 Antitrust Procedures in Abuse of Dominance, European Commission. Available at http://ec.europa.eu/competition/antitrust/procedures_102_en.html.

35 Gonzales-Diaz, F.E., Snelders, R. 2013, EU Competition Law, Claeys \& Casteels, Deventer, p. 68.

36 Ibid, p. 69.

37 Ibid, p. 116.

38 Rose, p. 412.

39 However it is extremely difficult to establish the exact amount of damage incurred Komninos A., 2009, Quantifying Antitrust Damages, Publications Office of the European Union, Luxembourg. Available at: http://ec.europa.eu/competition/antitrust/actionsdamages/quantification_study.pdf.

40 Rose, p. 226.

${ }^{41}$ Commission Notice on the definition of relevant market for the purposes of Community competition law, issued in the Official Journal C 372., art. 7
} 
and which can be distinguished from neighboring areas because the conditions of competition are appreciably different in those areas ${ }^{42}$. The definition of a relevant market in a case is important in the assessment of the infringement, establishment of the market share and in the calculation of a fine ${ }^{43}$. There are many tools used to establish a relevant market, such as the SSNIP test ${ }^{44}$. The outcome of the application of these tools should be a market that includes the product in questions and its substitutes.

When public licenses are concerned, however, many common tests used to establish a relevant product market tend to fail. For example the SNIPP test $^{45}$ uses a small increase in price (usually $5-10 \%$ ) and observes the changes in demand. If the demand moves to another product, such product belongs to the same relevant market ${ }^{46}$. The reason, why it fails in public licenses is obvious - $10 \%$ increase from zero price is still zero, therefore no changes in demand can be observed.

To establish a relevant product market, functional approach ${ }^{47}$ must be used. In the assessment of the relevant product market, it is necessary to analyse the functions the product fulfils, means it uses, resources it requires, guarantees it offers and potentially a long list of other criteria that appear on a case by case basis. It is also necessary to keep in mind, that such analysis is sensitive to subjective perception of the criteria used, therefore objective verification, such as market studies and surveys should be used.

From the abovementioned market tests, one rule can be deduced. A substitute product, offered on significantly more favourable terms (for example much cheaper or even free) would, in the long run, push the less favourable product out of the market ${ }^{48}$. This, however, did not happen with products licensed under public licenses compared to products licensed by

42 Commission Notice on the definition of relevant market for the purposes of Community competition law, issued in the Official Journal C 372., art. 8

43 Definition of Relevant Market, European Commission. Available at:

http://europa.eu/legislation_summaries/competition/firms/126073_en.htm.

44 Small but Significant and Non-transitory Increase in Price.

45 Gonzales-Diaz, p. 7.

46 Moresi, S.X., Salop S.C., Woodbury J. R.,2008, Implementing the Hypothetical Monopolist SSNIP Test with Multi-Product Firms. The Antitrust Source. Available at: http://www.americanbar.org/content/dam/aba/publishing/antitrust_source/Feb08_Moresi.a uthcheckdam.pdf

47 Also described as qualitative approach, Gonzales-Diaz , p. 18.

48 Niels, G., Jenkins, H., Kavanagh, J. 2011, Economics for Competition Lawyers. Oxford University Press, Oxford, p. 32. 
more traditional licensing schemes. A conclusion, that just a long existing difference in a license (public or other) can justify a classification of the products with the same function as belonging to different relevant markets, seems to be valid.

Another reason, why the relevant market definition is important, is the establishment of a market share. The size of a market share is relevant in the abuse of dominance concepts or in assessment of the severity of an infringement ${ }^{49}$. This concept does not seem to fit public licensing very well.

In traditional product markets, a market share can be calculated by assessing the number of units sold or provided and the revenues made ${ }^{50}$. In public licensing, there is no revenue at all to be assessed. This means, that this method would lead to a conclusion, that with public licenses, all the market shares are zero. This is not a correct conclusion. The method, based on the number of units provided, does provide some results, but they do not seem to be accurate. As the customer has to pay only transaction costs, but no actual price, he can easily decide to simply try a public licensed product he would never opt for if there were a price tag on it. Therefore, an actual sale of a product that includes a money transfer differs significantly from a simple provision of a public licensed product at a zero price and only transactional costs. To conclude, none of the abovementioned methods seems to produce a sufficiently accurate outcome. Yet again, we must use the functional approach and market survey to establish how many of the provided products are actually actively used. This approach should provide more credible results.

At this point, it is important to notice one important question, asked by Rubinfeld and Gal - What is the cost of free goods ${ }^{51}$ ? The idea of this question is, that many kinds of goods provided for free are not really for free. The consideration in question can be non-monetary, such as advertising or influence. We can also think of two-sided or even multi-sided markets. In these markets, the market strength gained in the market with a public license can be abused on other markets, on other side of the two- or multisided market ${ }^{52}$. This would require a deep study into the functioning of such markets, which is beyond the scope of this article. I will, therefore,

\footnotetext{
49 Rose, p. 763.

50 Ibid.

51 Rubinfeld, D., Gal, M.S. 2014 'The Hidden Costs of Free Goods: Implications for Antitrust Enforcement'. US Berkeley Public Research Paper no. 2529425.
} 
keep my focus on the so-called real free goods with no consideration whatsoever.

\section{POSSIBLE ABUSES OF COMPETITION CAUSED BY PUBLIC LICENCES}

The abovementioned introduction leads to a conclusion, that there are three basic possible abuses relevant to public licenses. These would be a price fixing cartel, a margin squeeze/dumping and an RPM. This part of the article will analyse them separately using the background from previous chapters and attempt to reach a conclusion, whether these are actual abuses of public licenses or not.

The evidence of a price fixing in public licenses takes the form of the fact that the works are provided for free in connection with the SA clause ${ }^{53}$. This basically means, that all those, who provide the licensed product, agree to provide it on similar terms and for a fixed price. This conclusion is correct; however it would be unreasonably early to finish the analysis with this result and conclude that there is a cartel.

The very idea of a price fixing cartel is based on an assumption that the price is fixed on a basis that is higher than a market price, to the detriment of a consumer. The idea of an exclusionary cartel is that the price is below the market price, but will be increased above it, once the undertakings not involved in the cartel will leave the market, to recoup the incurred losses and gain profit, yet again to the detriment of the consumer. Therefore, the cartel increases prices on the market, right away or after partial objectives are met $^{54}$.

None of this is possible with the use of public licenses. They do not provide anyone with the power to increase the price, immediately or in any time in the future. The price set by the public license is zero that is the lowest possible price. Therefore, it is not possible to establish any detriment to a consumer, real or potential. Under such circumstances, we cannot conclude, that there is a cartel, price fixing nor exclusionary.

\footnotetext{
52 Such market situation appears with Google and its search function (provided for free) connected with the advertising bussiness (paid by advertisers) and content provision (both paid and free), payment cards with free issuing (by card-holders, although not exclusively free) and paid acquiring (by merchants) sides.

53 See footnote 12 above

54 Rose, p. 301.
} 
The evidence of a margin squeeze/dumping is similar to that of a cartel, that is the requirement for the works to be provided for free. The difference is, that the margin squeeze/dumping are relevant in vertical relationships on the market involving a dominant undertaking.

We have assessed the difficulties in establishing market power in the previous chapter. Even with these in mind, a market situation with a large market share held by a product under public license is possible. Such market share can even fit the rebuttable presumption, that it provides a foundation for market dominance. However, market dominance is defined as a market position so strong, that the dominant undertaking can behave independently on its suppliers, competitors and customers ${ }^{55}$. Such independence can take forms of pricing behaviour or the business conditions imposed ${ }^{56}$. It is possible to conclude, that such independence must be related to important aspects of the undertakings business policy. To establish market dominance in relation to public licenses, further analysis is required.

The main point of such analysis has to be, whether a public license can allow independent behaviour of an undertaking. A public license is relatively restrictive in this manner. Both price and business conditions are quite beneficial for the customer, however also quite strictly set by the license. The restrictive nature of these provisions is common to public licenses in general. An undertaking, that decides to opt for a public licensing scheme, will not be able to avoid these provisions. In turn, these provisions lead to the limitation of the independence of the undertakings market behaviour, once the decision to opt for public license is made. In general, we can conclude, that public license, used for a product, is a limiting factor in pronouncing market dominance of an undertaking based on such a product.

Abuse of dominance is a concept that can barely be applied to public licenses. One reason is the abovementioned difficulty with establishing the market dominance as a preliminary condition for an abuse. The other reason is the fact, that we can find it difficult to establish a type of an abuse that fits possible situations with public licenses.

\footnotetext{
55 Hoffmann-La Roche \& Co. AG v Commission of the European Communities - Case 85/76.

56 Rose, p. 791.
} 
The best fitting type of an abuse, that could be related to public licenses, would be margin squeeze/dumping ${ }^{57}$. In a margin squeeze/dumping scheme a dominant undertaking drops its prices below costs or imposes business conditions that cannot be countered by other undertakings in the market, while taking loses. This creates pressure on other undertakings on the market and should cause them to leave the market. Once this happens, the dominant increases its prices or changes the business conditions and recoups its loss incurred ${ }^{58}$. As was discussed with exclusionary cartel, this is not possible with public licenses as no one has the legal means of increasing the price on a product under a public license ${ }^{59}$.

This conclusion can be also understood as further proof, showing that products licensed under public licenses and under traditional licenses form different markets. In many cases, we can see nearly similar products distributed under both kinds of licenses, parallel to each other for years ${ }^{60}$. Yet still, the public licensed product did not push the other product out of the market and has even not gained significant market share.

We can conclude, that public licenses do not threaten competition under the concept of abuse of dominance.

The last relevant market abuse relevant to public licenses would be the $R P M^{61}$. Under RPM, a supplier and customer agree on prices or conditions of further resale of a product. Such a vertical agreement is often used in order to limit intra-brand competition or mitigate the differences among distribution channels ${ }^{62}$. Their result is an increase in prices or less favourable business conditions for the end-customer or consumer. We can also clearly see that there has to be a price that can be increased by the RPM or business conditions that can be different among distribution channels. None of that is possible under public licenses. The assessment of an RPM

57 Deutsche Telekom AG v Commission of the European Communities - Case T-271/03.

58 Rose, p. 797.

59 Daniel Wallace vs. IBM Inc., Red Hat Inc., and Novell Inc. (no. 06-2454, 7th cir., Nov. 9 2006). 467 F.3d 1104 (7th Cir. 2006).

60 For example the Microsoft Office software being distributed alongside the OpenOffice and LibreOffice software. As it is difficult to measure market share of OpenOffice and LibreOffice, there are many studies showing different results. The gap between the market shares seems to stretch over $40-80 \%$. See also International OpenOffice market shares available at http://www.webmasterpro.de/portal/news/2010/02/05/international-openofficemarket-shares.html or Webanalyse: OpenOffice auf über $21 \%$ der Computer available at http://www.webmasterpro.de/portal/news/2010/01/25/verbreitung-von-office-programmenopenoffice-ueber-21.html.

61 Guidelines on Vertical Restraints, European Commission. Available at: http://ec.europa.eu/competition/antitrust/legislation/guidelines_vertical_en.pdf

62 Rose, p. 426. 
abuse is more complicated as it is a hard-core abuse ${ }^{63}$, however the application of the safe harbour of Art. 101/3 TFEU should be a sufficient measure to declare public licenses compliant with competition law.

We can therefore conclude that public licenses do not constitute a RPM abuse.

The general conclusion to be drawn from this chapter is that public licenses do not constitute an abuse of competition law. However, it is also important to notice, that this conclusion is valid only on relevant markets other than two-sided or multi-sided. On such markets, the market power gained on one side can be misused on the other. Such scenarios are potentially relevant as comparable cases already exist ${ }^{64}$.

\section{PROCEDURAL ASPECTS}

The research question of this paper brings certain procedural aspects that should not be omitted in the assessment of the conclusions. Such aspects constitute large obstacles to possible investigation by a competition authority into alleged anticompetitive practises involving public licenses.

The first obstacle to be tackled is the establishment of the parties to a proceeding $^{65}$. As we understand from previous chapters, public licensed products can be always freely distributed, if the relevant conditions are met. On a following basis, many such products allow for alterations by others. Under such conditions, it is impossible to establish, who was the creator and distributor of a product that caused the investigated infringement and therefore should be a party to a proceeding. The original work before all possible alterations can be very different from the product that has caused the infringement; therefore its author should not be liable for it as his work had nothing to do with the infringement. On the other hand, the authors of alterations, modifications or improvements have all contributed with minor changes to a work. None of such contributors should then be liable for the whole product. It is also important to notice, that such contributors might be located in many different jurisdictions, which makes the investigations even more complicated.

\footnotetext{
63 Art. 4, Commission regulation 330/2010 on the application of Art. 101/3 TFEU to categories of vertical agreements and concerted practises.

64 Such as the current Google case No. 39740 with case information available at http://ec.europa.eu/competition/elojade/isef/case_details.cfm?proc_code=1_39740

65 Svetlicinii, A. 2011, Who is to Blame? Liability of 'Economic Units' for Infringements of EU Competition Law, European Law Reporter, vol. 2, p. 52 - 56.
} 
It is also impossible to establish, who the distributor with a market share is as anyone acquiring a copy of the product might be a distributor as well. Relating a number of provided licenses or a market share to a single subject or a definitive list of sufficiently identified subjects might be excessively difficult or even impossible.

For these reasons, a competition authority might find it impossible to establish parties to a proceeding with appropriate reasoning.

The second obstacle is the calculation of a fine ${ }^{66}$. In many legal systems, the fine is calculated on a basis of sales of a product affected by the agreement or practise ${ }^{67}$. With public licenses, the basis would equal to zero as there is zero price.

For this reason, it is impossible to calculate a fine using the established methods.

The third and last obstacles to be discussed are the interim measures ${ }^{68}$ and commitments ${ }^{69}$. A competition authority can award interim measures or accept commitments that should remove the anticompetitive constraint from the market and allow for undistorted competition. Such measures include an enforced change in business practices, a ban on further fulfilment of a cartel or other suitable means ${ }^{70}$. All of these means should be addressed to a specific subject and can be enforced upon them.

With public licenses, however, interim measures do not seem to work. It is impossible to address them to a liable undertaking as the relevant undertakings might be outside of its jurisdiction or unable to actually perform these measures. At any time, there can be a subject outside the jurisdiction of the competition authority or unaware of its decision that can provide all the other users of the product with a valid license to the product in question.

To conclude this chapter, investigation by a competition authority would face significant difficulties form the very beginning to the end. These difficulties seem impossible to overcome in a constructive way. This

${ }^{66}$ Guidelines on the method of setting fines imposed pursuant to Article 23(2)(a) of Regulation No 1/2003, European Commission, available at:

http://europa.eu/legislation_summaries/competition/firms/126118_en.htm

67 Ibid.

68 Antitrust Manual of Procedures, European Commission, 2012. Available at: http://ec.europa.eu/competition/antitrust/antitrust_manproc_3_2012_en.pdf, p. 191.

69 Council Regulation $1 / 2003$ on the implementation of the rules on competition laid down in Articles 81 and 82 of the Treaty, art. 9.

70 Antitrust Manual of Procedures, p. 177. 
significantly limits the chances of a successful case by the competition regulator.

\section{CONCLUSIONS}

At the first glance, public licenses might cause significant competitive constraints. However, after deeper assessment, study of the provisions of common public licenses, assessing most important competition law infringements and applying competition law concepts on public licenses, the only valid outcome is that public licenses do not constitute a competition law infringement. A competition authority, that would attempt to verify this conclusion by an investigation, would face significant obstacles that cannot be overcome within current legal means.

\section{LIST OF REFERENCES}

Välimäki, M. 2005, Rise of Open Source Licensing, Turre Pulishing, Helsinki Rose, V., Bailey, D. 2013, European Union Law of Competition, Oxford University Press, Oxford.

Gonzales-Diaz, F.E., Snelders, R. 2013, EU Competition Law, Claeys \& Casteels, Deventer.

Moresi, S.X., Salop S.C., Woodbury J. R., 2008, Implementing the Hypothetical Monopolist SSNIP Test with Multi-Product Firms. The Antitrust Source. Available at:

http://www.americanbar.org/content/dam/aba/publishing/antitrust_source/

Feb08_Moresi.authcheckdam.pdf

Niels, G., Jenkins, H., Kavanagh, J. 2011, Economics for Competition Lawyers. Oxford University Press, Oxford.

Rubinfeld, D., Gal, M.S. 2014 'The Hidden Costs of Free Goods: Implications for Antitrust Enforcement'. US Berkeley Public Research Paper no. 2529425.

Svetlicinii, A. 2011, Who is to Blame? Liability of 'Economic Units' for Infringements of EU Competition Law, European Law Reporter, vol. 2. 